\begin{tabular}{|l|l|l|l|l|l|}
\hline J. Tek. Ling & Vol. 12 & No. 3 & Hal. 299 - 308 & Jakarta, September 2011 & ISSN 1441-318X \\
\hline
\end{tabular}

\title{
KARAKTERISASI SUMBERDAYA LAHAN DAN PEWILAYAHAN KOMODITAS UNGGULAN PERKEBUNAN DI PULAU BURU
}

\author{
Mubekti \\ Peneliti di Pusat Teknologi Inventarisasi Sumberdaya Alam - TPSA \\ Badan Pengkajian dan Penerapan Teknologi
}

\begin{abstract}
Abstrak
Evaluasi karakter lahan dan pewilayahan komoditas perkebunan berdasarkan kesesuaian lahan telah dilakukan di Pulau Buru, dimana wilayah ini merupakan salah satu pulau utama di Provinsi Maluku yang mempunyai potensi sumberdaya lahan yang tinggi. Namun demikian karakter lahan sangat bervariasi dari satu tempat ke tempat lainnya karena adanya factor-faktor pembatas di dalamnya. Dalam metodologi dijelaskan secara singkat tentang evaluasi lahan, kesesuaian lahan dan pewilayahan komoditas perkebunan. Kemudian bahasan hasil studi di Pulau Buru disajikan meliputi penggunaan, karakter, dan kesesuaian lahan, serta pewilayahan komoditas perkebunan. Sebagian besar wilayah studi masih ditutupi oleh hutan, dan hanya sebagian kecil yang dimanfaatkan sebagai lahan garapan. Dareah studi terdapat 5 fisiografi terbagi menjadi 15 unit lahan. Sebagian besar lahan masuk dalam katagori tidak sesuai $(N)$, dan hanya sebagian kecil yang masuk katagori sesuai (S). Secara alami yang menjadi factor pembatas lahan adalah kemiringan curam, ketinggian tempat, kedalaman tanah yang dangkal, dan ketersediaan air. Total luasan lahan yang potensial untuk dikembangkan sebagai lahan perkebunan adalah 187.902 hektar, dan sekitar $50 \%$ dari lahan tersebut terletak di hutan yang dapat dikonversi.
\end{abstract}

Kata Kunci: Evaluasi lahan, kesesuaian lahan, pewilayahan komoditas, pertanian

\begin{abstract}
The evaluation of land characteristics and plantation crop zoning based on its land suitability was conducted in Buru Island. Buru is one of the main islands in Maluku Province which has a high potency of land resource. In fact, the quality of land varies from one place to the others due to the presence of limiting factors in it. A brief explanation of land resources evaluation, land suitability and commodity zoning for plantation crop is presented in the methodology. Then, the results of study including land use, land characterization, land suitability and land zoning in Buru island are discussed. Most of the land of Buru island are still covered by forest trees, and only a small part is utilized as arable land. There are 5 structural physiographic of land in the study area divided into 15 land units. The result of suitability analysis shows that the most of the lands is classified as Not-Suitable (N), whereas a few land is classified as Suitable (S). By nature those lands have several main limiting factors, i.e. steep slope, elevation, shallow soil dept, and water availability. The acreage of land which has a potential to develop for plantation crop is 187.902 hectars and about a half of those area is located in forest conversion area.
\end{abstract}

Key words: land evaluation, land suitability, commodities zoning, GIS, agriculture 


\section{PENDAHULUAN}

\subsection{Latar Belakang}

Lahan merupakan sumberdaya alam yang terbatas dan tidak dapat diperbaharui, sedangkan dipihak lain manusia yang memerlukan lahan secara nasional jumlahnya terus bertambah dengan laju pertumbuhan 3,25 juta jiwa per tahun'1). Konflik penggunaan lahan dan benturan kepentingan antar sektoral dapat terjadi akibat dari pertambahan penduduk dan pesatnya laju pembangunan. Oleh karena itu diperlukan upaya perencanaan secara terpadu, tentang penggunaan lahan. Penilaian potensi lahan sangat diperlukan terutama dalam rangka penyusunan kebijakan, pemanfaatan lahan dan pengelolaan lahan secara berkesinambungan.

Pulau Buru adalah salah satu pulau utama di Provinsi Maluku yang mempunyai luasan 860.787 ha, di samping Pulau Seram, dan pulau-pulau lainnya. Komoditas perkebunan mempunyai prospek yang baik untuk dikembangkan di wilayah ini. Potensi sumber daya lahan di Pulau Buru sangat beragam karena adanya perbedaan iklim, bahan induk, tanah, dan topografi/ relief. Besarnya keragaman dalam karakter dan potensi lahan tersebut memerlukan pengelompokan kedalam satuan-satuan yang lebih seragam yang memiliki potensi yang sama atau hampir sama. Setiap satuan lahan mempunyai sifat karakteristik fisik yang sama dan mempunyai daya dukung untuk peruntukan tertentu. Keragaman karakteristik suatu lahan bersifat sistematik, sehingga dapat dipetakan berdasarkan satuan-satuannya.

Komoditas perkebunan yang mempunyai potensi dan diunggulkan oleh daerah adalah kelapa, kakao, pala dan cengkeh. Komoditas unggulan disini didefinisikan sebagai komoditas-komoditas yang sudah dibudidayakan masyarakat setempat selain dibutuhkan oleh masyarakat juga dapat meningkatkan pendapatan masyarakat dan juga pemerintah daerah. Namun demikian informasi tentang kesesuaian lahan dan pewilayahan potensi sumberdaya lahan untuk komoditas unggulan perkebunan belum tersedia di wilayah ini.

\subsection{Tujuan}

Tujuan dari studi ini adalah melakukan evaluasi lahan untuk memberikan informasi tentang karakter sumberdaya lahan di Pulau Buru. Berdasarkan karakter lahan kemudian dilakukan evaluasi kesesuaian dan pewilayahan komoditas unggulan perkebunan.

\section{METODOLOGI}

\subsection{Bahan}

Pelaksanaan kegiatan karakterisasi sumberdaya lahan dan pewilayahan komoditas unggulan perkebunan di Pulau Buru, didahului dengan pengumpulan data sekunder yang meliputi: (1) Atlas Sumberdaya Tanah Eksplorasi Indonesia, (2) Zone agroekologi Dataran Waeapo, (3) Peta Tataguna Hutan Kesepakatan, Provinsi Maluku, (4) Peta Topografi, (5) Peta Penggunaan Lahan, (6) Peta Geologi Pulau Buru dan Seram, (7) Data SRTM dan (7) Citra Satelit Landsat TM tahun 2007). Kemudian data sekunder tentang potensi sumberdaya alam di Pulau Buru diperoleh dari Pemerintah Daerah, serta data primer dari survai lapangan dalam rangka karakterisasi sifat bio-fisik lahan dan pengambilan sampel tanah.

\subsection{Metoda}

Penelitian ini meliputi pekerjaan di kantor dan survai lapangan, dimana pekerjaan kantor meliputi telaah pustaka, analisis lab, evaluasi dan pemetaan tanah, sedangkan survai lapangan meliputi pengambilan sampel tanah, verifikasi karakter bio-fisik lahan. Tahapan yang dilakukan adalah 
evaluasi satuan lahan, evaluasi persyaratan tumbuh komoditas unggulan perkebunan, yaitu kelapa, kakao, pala, dan cengkeh, serta evaluasi kesesuaian lahan untuk masing-masing komoditas perkebunan. Klasifikasi peta satuan lahan didasarkan pada parameter-parameter fisik lahan yang menjadi faktor pembatas apabila akan dimanfaatkan untuk pengembangan komoditas perkebunan ${ }^{2)}$. Parameterparameter tersebut meliputi: (1) kemiringan lereng; (2) tingkat kerentanan erosi; (3) tingkat kerentanan banjir; (4) kedalaman tanah; (5) tekstur tanah; (6) drainase tanah; (7) keasaman tanah; (8) salinitas; (9) iklim.

Prinsip dari analisis kesesuaian lahan adalah mencocokkan persyaratan tumbuh tanaman dengan kualias lahan3,4,5). Penentuan kelas kesesuaian berdasarkan faktor-faktor pembatas lahan yang diperoleh dari peta satuan lahan. Kelas kesesuaian lahan dikelompokkan dalam katagori: (1) Kelas S1: sangat sesuai, (2) Kelas S2 : cukup sesuai, (3) Kelas S3 : sesuai marginal, dan (4) Kelas N : tidak sesuai. Sedangkan strategi pentahapan evaluasi dengan ALES (Rossiter, D. G., and A. R. Van Wambeke. 1997). Tahapan terakhir adalah penentuan pewilayahan komoditas unggulan perkebunan berdasarkan kombinasi kelas kesesuaian dari masing-masing komoditas.

\section{KONDISI UMUM WILAYAH}

\subsection{Kondisi Geografi}

Pulau Buru yang pada jaman orde baru dijadikan tempat tahanan politik (Tapol) terletak antara $2^{\circ} 25^{\circ}-3^{\circ} 55^{\circ} \mathrm{LS}$ dan $121^{\circ} 21^{\circ}$ - $15^{\circ} 21^{`}$ BT. Pulau Buru dibatasi oleh Laut Seram di sebelah utara, Laut Banda di sebelah selatan, Laut Buru di sebelah barat dan Selat Manipa di sebelah timur. Pada tahun 2008 Pulau Buru dimekarkan menjadi 2 Kabupaten, yaitu Kabupaten Buru dan Kabupaten Buru Selatan (UU no. 32, 2008). Kabupaten Buru membawahi Kecamatan Air Buaya, Waplau, Waeapo, Namlea dan Bata Bual. Sedangkan Kabupaten Buru Selatan membawahi Kecamatan Kepala Madan, Leksula, Namrole, Waisama, dan Ambalau (Gambar 1).

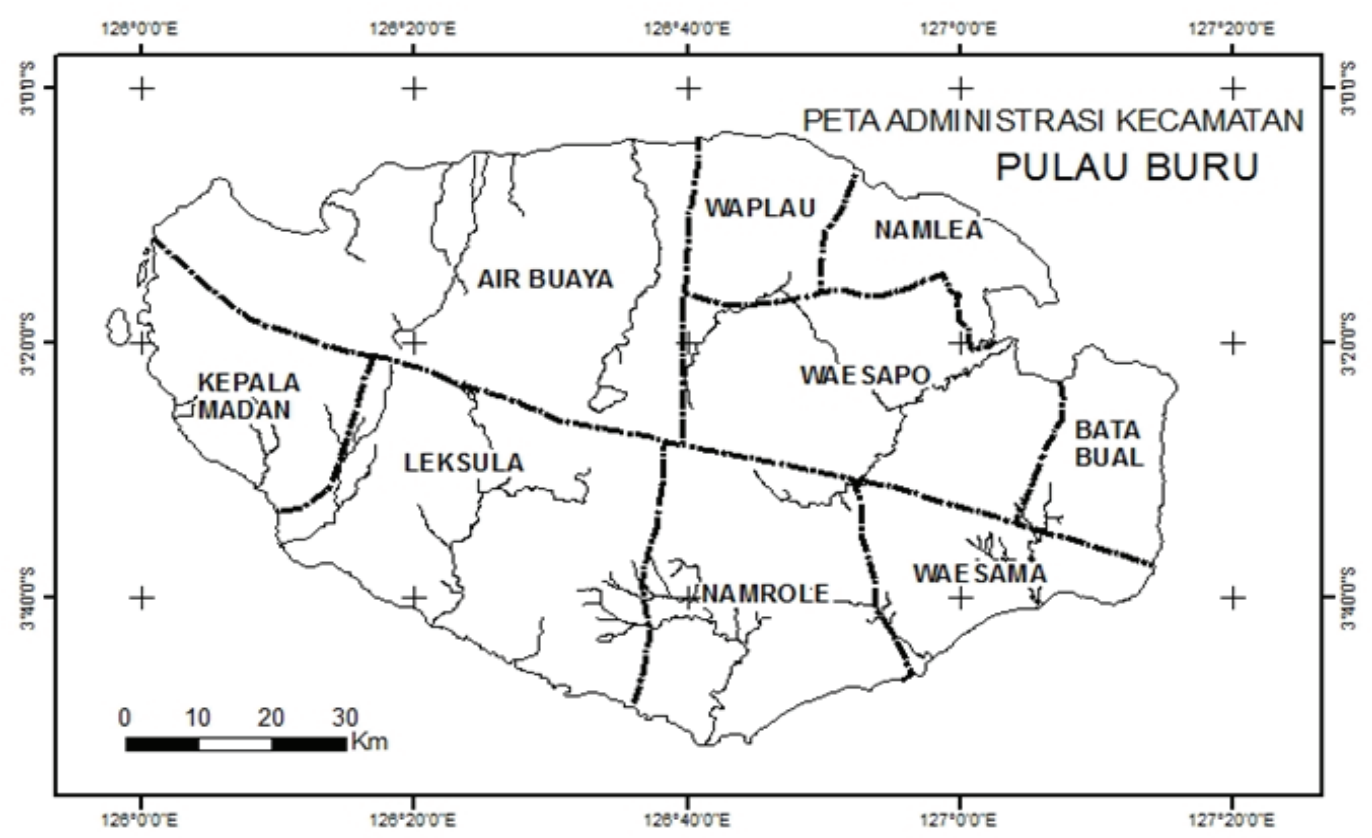

Gambar 1. Peta Administrasi Pulau Buru 
Secara total Pulau Buru mempunyai luasan $12.656 \mathrm{~km} 2$, sedangkan luasan masing-masing kecamatan bervariasi. Kecamatan dengan wilayah terluas adalah Air Buaya yang mencapai $4.534 \mathrm{~km} 2$ atau $35.8 \%$ dari luas Pulau Buru. Kecamatan dengan luas area terkecil adalah Bata Bual yang hanya memiliki luas $293 \mathrm{~km} 2$ atau sekitar 2.3\% dari seluruh luas Kabupaten Buru.

\subsection{Kondisi Iklim}

Pulau Buru memiliki iklim tropis dan iklim muson yang dipengaruhi oleh angin musim serta berhubungan erat dengan lautan yang mengelilinginya. Ciri umum dari curah hujan tahunan rata-rata dibagi dalam 4 kelas, yaitu: (1) Buru Bagian Utara 1400 - 1800 mm/tahun, (2) Buru Bagian Tengah 1800 - 2000 mm/tahun, (3) Buru Bagian Selatan 2000 - 2500 mm/tahun, dan (4) Kawasan berelevasi lebih dari 500 $\mathrm{m}$ dari permukaan laut dengan rata-rata 3000 - 4000 mm/tahun. Menurut Koppen, iklim daerah Pulau Buru, di sebelah utara (Namlea) termasuk dalam kategori klasifikasi Awa, dan termasuk dalam kategori kelas $D$ dalam Schmidt dan Ferguson dengan rata-rata 6,1 bulan basah dan 4,2 bulan kering. Iklim daerah Pulau Buru, di sebelah tengah dan selatan termasuk dalam kategori klasifikasi Afa menurut Koppen, termasuk dalam kategori klas B dalam Schmidt dan Ferguson dengan rata-rata 8,4 bulan basah dan 2,6 bulan kering.

\subsection{Geologi dan Bahan Induk Tanah}

Geologi Pulau Buru membentuk fisiografi yang merupakan bagian akhir dari sebelah barat laut pegunungan membentuk Lingkar Banda. Lembar geologi Pulau Buru6) menyatakan bahwa geologi Pulau Buru terdiri dari banyak formasi berasal dari zaman Permian Karbon sampai ke Holosen (sekarang). Pada zaman Permian dan Karbon terbentuk batuan-batuan metamorfik atau malihan yaitu termasuk didalamnnya adalah kompleks batuan yang termasuk dalam kompleks Rana dan kompleks Wahlua.

Pulau Buru bagian tengah dan utara kebanyakan dipetakan dalam peta geologi sebagai kompleks Roana dan Wahrua, terdiri dari phylit, slate, arkose, kuarsit, greywacke dan marmer. Adanya bahan sedimen yang lebih muda merupakan bagian yang sangat terangkat dan tersesar dalam formasi Dalan dan Ghegan. Batuan tersier hanya dapat diketemukan di daerah yang terpencar disekitar pulau, sebagai batuan sedimen, yang umumnya tererosi dari bahan yang terangkat oleh gaya tektonik di pulau ini. Bula diperbesar dalam era Kuarter dengan pertumbuhan dari batukapur karang di pantai utara dan pengisian teluk oleh bahan aluvium.

\subsection{Bentuk Lahan}

Pulau Buru merupakan pulau berbentuk oval bergunung-gunung, dan dikelilingi daerah datar yang sempit di wilayah pantai. Secara topografi, daratan di Pulau Buru memiliki ketinggian bervariasi dari $0 \mathrm{~m}$ dpl sampai tertinggi $2.736 \mathrm{~m} \mathrm{dpl} \mathrm{di} \mathrm{puncak}$ Gunung Kaku Ghegan di Kecamatan Kepala Madan. Dua gunung lainnya adalah Gunung Rana di bagian tengah, terletak di Kecamatan Air Buaya, dan Gunung Batabual di sebelah timur dengan tinggi masing-masing 2.000 $\mathrm{m}$ dpl dan $1.731 \mathrm{~m}$ dpl. Di timur laut ada depresi besar yang didrainasekan oleh Sungai Waeapu yang mungkin merupakan hasil patahan. Bibir pantai di daerah pesisir diratakan oleh erosi laut (abrasi) yang kuat, tampak pada sejumlah teluk yang ada di pulau tersebut. Gambar 2, menerangkan lebih detail tentang ilustrasi bentuk lahan Pulau buru yang diperoleh dari data SRTM (Shuttle Radar Topography Mission). 


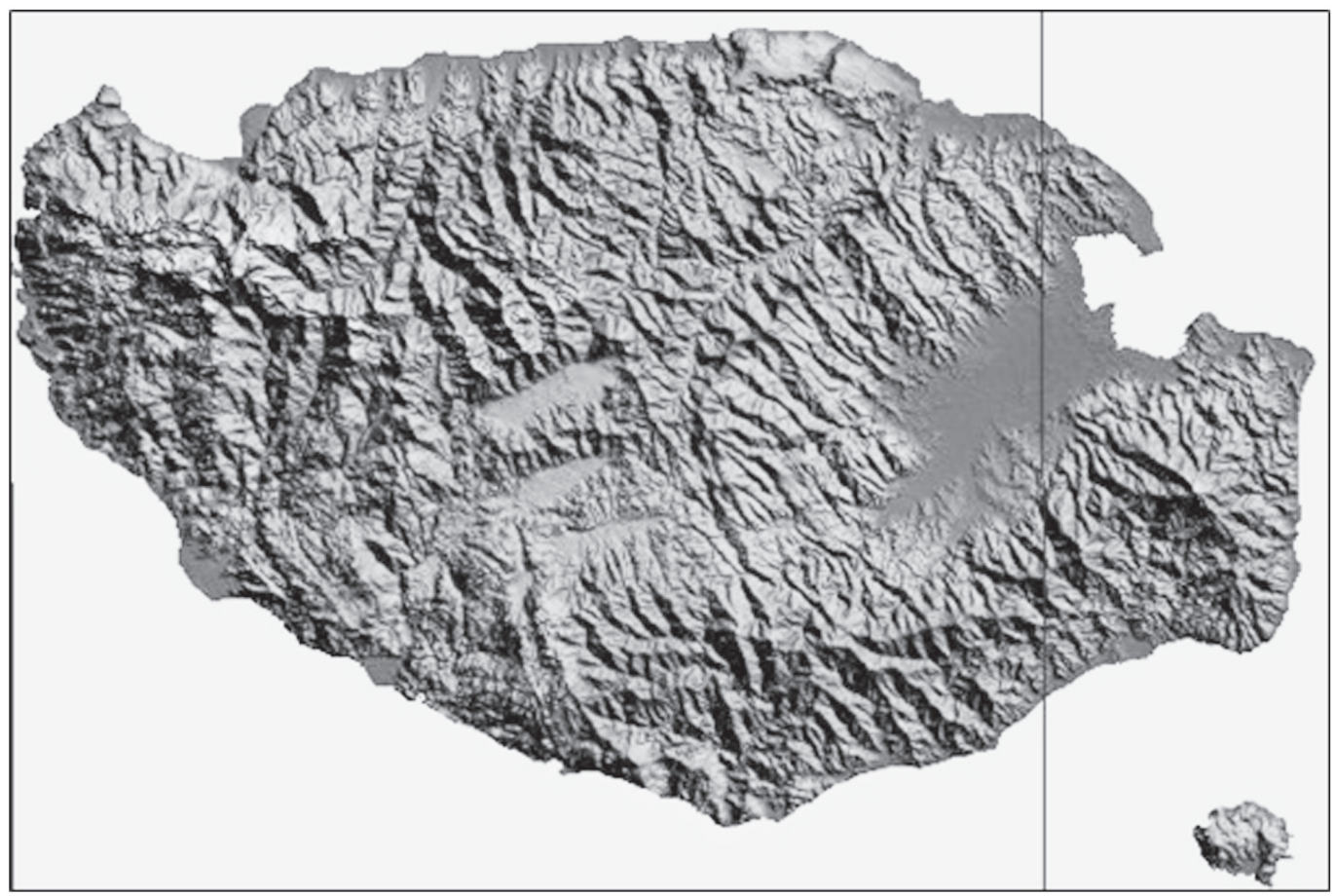

Gambar 2. Ilustrasi Bentuk Lahan Pulau Buru

Kebanyakan bagian dari Pulau Buru berasal dari batuan metamorfik, yang membentuk lungur-lungur pegunungan7). Diatas batuan yang lebih tua ini terdapat batuan sedimen yang lebih muda, di bagian barat daya dan utara pulau ini merupakan bahan berkapur. Batupasir tidak berkapur, batu sabak dan konglomerat muncul sebagai bagian dari alur lungur yang melintas DAS tertinggi dan bagian paling timur dari pulau ini.

\section{KARAKTERISASI LAHAN}

\subsection{Penggunaan/Tutupan Lahan}

Hasil analisis Citra Landsat TM tahun 2007 yang dilengkapi dengan data pengamatan lapangan, menghasilkan klasifikasi penggunaan lahan. Penggunaan lahan terdiri atas: sawah, rumput, semak belukar, tegalan dan kampung, kayuputih, kelapa dan kebun campuran, hutan primer, hutan sekunder, mangrove, hutan sagu, dan lahan terbuka.

Persawahan hanya terkonsentrasi pada satu kecamatan saja, yaitu Kecamatan Waeapo seluas 8.900 ha tersebar sepanjang jalur sungai Waeapo. Rumput dan semak seluas 2.685 ha tersebar dari Kecamatan Namlea bagian tengah-selatan bersambung ke Waeapo bagian timur laut. Semak belukar terdapat pada perladangan berpindah, seluas 10.749 ha. Tegalan umumnya terletak di sekitar kampung dengan luasan total sekitar 21.667 ha. Pada umumnya tegalan ini ditanami padi dan ubi kayu. Semak bercampur pepohonan kayu putih merupakan vegetasi spesifik, tersebar di Namlea, Wapplau, Waeapo, dan di Kabupaten Buru Bagian Selatan tersebar di dataran tinggi bagian timur. Kelapa merupakan komoditas utama yang dihasilkan oleh Pulau Buru. Kebun kelapa dengan luasan 2.212 ha umumnya di sepanjang pantai utara dan pantai selatan, terutama di Kecamatan Airbuaya. Hutan sekunder merupakan tutupan lahan dominan dengan 
luasan total 217.834 ha tersebar di seluruh wilayah, baik Buru Utara maupun Buru Selatan. Hutan mangrove seluas sekitar 4.000 ha, terutama terletak di muara sungai Waeapo. Lahan terbuka yang ada di Pulau Buru merupakan lahan akibat penebangan hutan yang dilanjutkan dengan erosi yang terus menerus. Luas total lahan terbuka sekitar 22.000 ha terutama pada daerahdaerah berombak.

\subsection{Pemetaan Satuan Lahan}

Peta satuan lahan merupakan dasar dalam penilaian kesesuaian lahan. Peta ini dibangun dari analisis dan interpretasi data SRTM, Citra satelit Landsat TM, dan didukung peta geologi skala 1:250.000 Pulau Buru serta data atau peta hasil penelitian terdahulu. Peta tanah atau satuan lahan yang telah ada yakni di Dataran Waeapo (Pulau Buru) seluas +52.500 ha. Berdasarkan hasil interpretasi, pengamatan lapang dan didukung data hasil analisis laboratorium daerah Pulau Buru dibedakan atas 77 Satuan Lahan dari Grup Fisiografi dan 4 Satuan Lahan dari Grup Aneka, namun dalam tulisan ini diringkas menjadi 15 satuan lahan, dan satu grup aneka. Grup fisiografi tersebut adalah Aluvial, Fluvio Marin, Marin, Karst, dan Grup Tektonik/Struktural. Sedangkan jenis tanah menurut sistem taksonomi tanah8) yang mendominasi wilayah adalah Entisols, Histosols, Mollisols, Inceptisols, dan Alfisols. Penyebarannya pada Peta Satuan Lahan seperti yang terlihat dalam Gambar 3, dan ekstraksi luasannya tercantum dalam Tabel 1.

Dari Tabel 1 terlihat, bahwa satuan lahan pada fisiografi tektonik yang mendominasi lahan, yaitu mencapai luasan 666.653 hektar atau $77,5 \%$ dari total luas Pulau Buru. Satuan lahan pada fisiografi alluvial mencapai luasan 73.435 hektar atau 8,6 \% dari total wilayah. Satuan lahan pada fisiografi Karst mencapai luasan 85.457 hektar atau 10,0 \% dari total luas wilayah. Sedangkan satuan lahan pada fisiografi marin yang paling kecil luasannya, yaitu 32.839 hektar atau 3,9 \% dari total luas Pulau Buru.

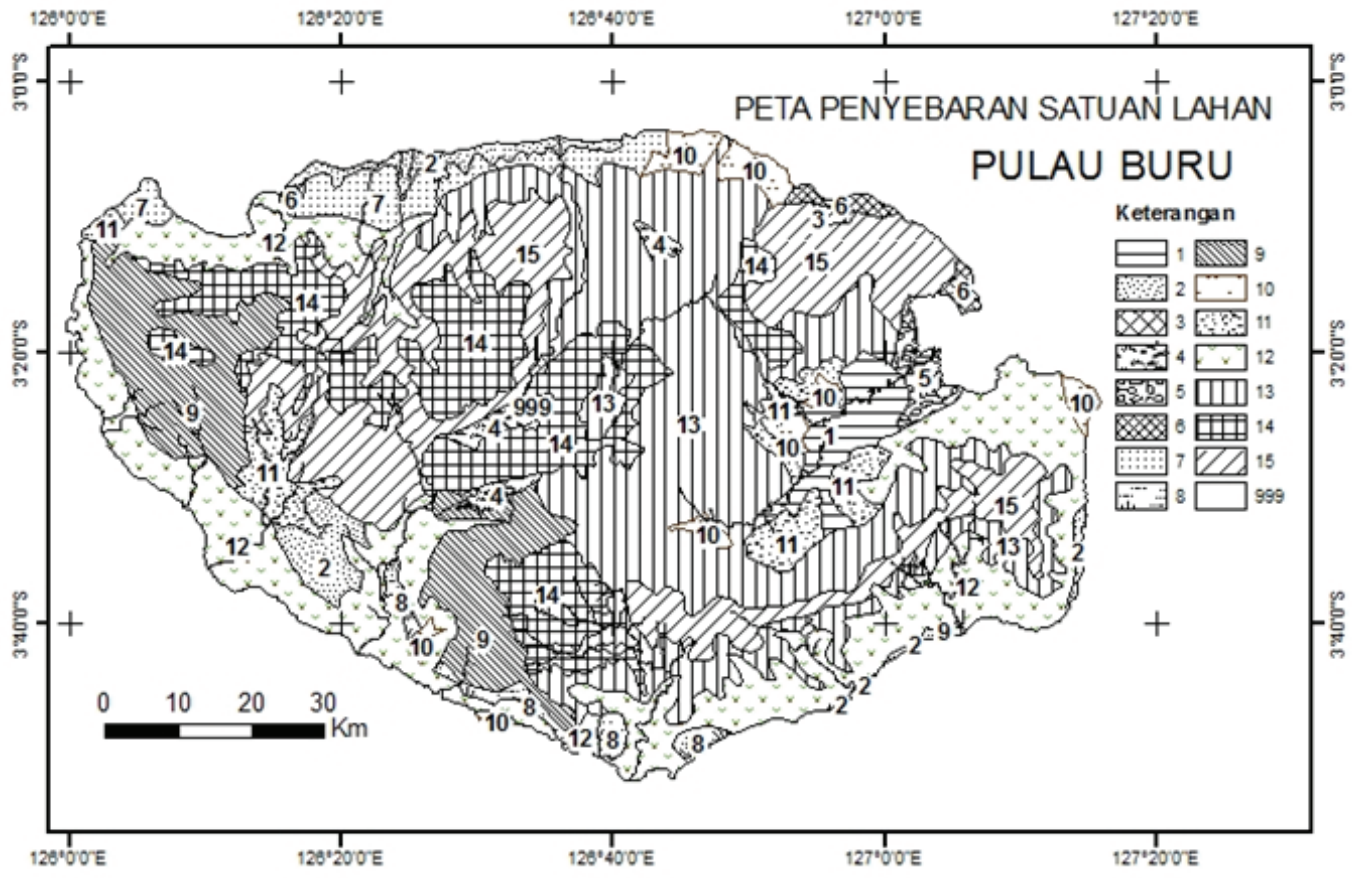

Gambar 3. Peta penyebaran satuan lahan, Pulau Buru 
Tabel 1. Legenda Peta Satuan Lahan/Tanah Pulau Buru

\begin{tabular}{|c|c|c|c|c|c|c|c|}
\hline SPT & $\begin{array}{c}\text { Fisiografi/ } \\
\text { Bentuk } \\
\text { Lahan }\end{array}$ & Relief & $\begin{array}{l}\text { Elevasi } \\
\text { (m dpl.) }\end{array}$ & Bahan Induk & $\begin{array}{c}\text { Tanah } \\
\text { Dominan }\end{array}$ & $\begin{array}{l}\text { Luas } \\
(\mathrm{Ha})\end{array}$ & $\%$ \\
\hline \multicolumn{6}{|c|}{ GRUP ALUVIAL: } & 73.435 & 8,6 \\
\hline 1 & $\begin{array}{l}\text { Dataran } \\
\text { aluvial }\end{array}$ & agak datar & $<100$ & Aluvium & $\begin{array}{l}\text { Typic } \\
\text { Eutrudepts }\end{array}$ & 35.172 & 4,1 \\
\hline 2 & $\begin{array}{l}\text { Dataran } \\
\text { koluvial }\end{array}$ & agak datar & $<100$ & aluvium & $\begin{array}{l}\text { Typic } \\
\text { Hapludalfs }\end{array}$ & 21.507 & 2,5 \\
\hline 3 & \begin{tabular}{|l|} 
Dataran \\
koluvial
\end{tabular} & berombak & $<100$ & aluvium & $\begin{array}{l}\text { Typic } \\
\text { Hapludalfs }\end{array}$ & 6.370 & 0,8 \\
\hline 4 & $\begin{array}{l}\text { Basin } \\
\text { tertutup }\end{array}$ & agak datar & $400-700$ & Aluvium & $\begin{array}{l}\text { Typic } \\
\text { Eutrudepts }\end{array}$ & 10.386 & 1,2 \\
\hline \multicolumn{6}{|c|}{ GRUP MARIN: } & 32.839 & 3,9 \\
\hline 5 & \begin{tabular}{|l|} 
Dataran \\
pasang surut
\end{tabular} & datar & $<100$ & $\begin{array}{l}\text { Bahan } \\
\text { organik, } \\
\text { aluvium }\end{array}$ & $\begin{array}{l}\text { Typic } \\
\text { Sulfihemists }\end{array}$ & 6.658 & 0,8 \\
\hline 6 & $\begin{array}{l}\text { Teras marin } \\
\text { resen }\end{array}$ & berombak & $<100$ & $\begin{array}{l}\text { Bongkah, } \\
\text { kerakal, } \\
\text { kerikil, }\end{array}$ & $\begin{array}{l}\text { Typic } \\
\text { Eutrudepts }\end{array}$ & 7.657 & 0,9 \\
\hline 7 & $\begin{array}{l}\text { Teras marin } \\
\text { sub resen }\end{array}$ & bergelombang & $0-400$ & $\begin{array}{l}\text { Konglomerat, } \\
\text { batupasir }\end{array}$ & $\begin{array}{l}\text { Typic } \\
\text { Eutrudepts }\end{array}$ & 18.524 & 2,2 \\
\hline \multicolumn{6}{|c|}{ GRUP KARST: } & 85.457 & 10,0 \\
\hline 8 & \begin{tabular}{|l|} 
Perbukitan \\
Karst \\
\end{tabular} & $\begin{array}{l}\text { Agak curam- } \\
\text { curam }\end{array}$ & $400-700$ & Batugamping & $\begin{array}{l}\text { Typic } \\
\text { Eutrudepts }\end{array}$ & 29.707 & 3,5 \\
\hline 9 & $\begin{array}{l}\text { Pegunungan } \\
\text { Karst }\end{array}$ & $\begin{array}{l}\text { bergelombang- } \\
\text { curam }\end{array}$ & $700-1300$ & Batugamping & $\begin{array}{l}\text { Typic } \\
\text { Udorthents }\end{array}$ & 55.750 & 6,5 \\
\hline \multicolumn{6}{|c|}{ GRUP TEKTONIK/STRUKTURAL: } & 666.653 & 77,5 \\
\hline 10 & \begin{tabular}{|l|} 
Dataran \\
tektonik
\end{tabular} & Berombak & $0-400$ & \begin{tabular}{|l|} 
Napal, \\
batupasir, \\
serpih \\
\end{tabular} & $\begin{array}{l}\text { Typic } \\
\text { Eutrudepts }\end{array}$ & 20.794 & 2,4 \\
\hline 11 & $\begin{array}{l}\text { Dataran } \\
\text { tektonik }\end{array}$ & Berombak & $0-400$ & $\begin{array}{l}\text { Sekis, } \\
\text { kuarsit, } \\
\text { gneis, }\end{array}$ & $\begin{array}{l}\text { Typic } \\
\text { Eutrudepts }\end{array}$ & 26.498 & 3,1 \\
\hline 12 & $\begin{array}{l}\text { Perbukitan } \\
\text { tektonik }\end{array}$ & Agak curam & $400-700$ & $\begin{array}{l}\text { Batupasir, } \\
\text { serpih, } \\
\text { lempung, }\end{array}$ & $\begin{array}{l}\text { Typic } \\
\text { Eutrudepts }\end{array}$ & 159.740 & 18,6 \\
\hline 13 & $\begin{array}{l}\text { Perbukitan } \\
\text { tektonik }\end{array}$ & $\begin{array}{l}\text { bergelombang- } \\
\text { curam }\end{array}$ & $400-700$ & \begin{tabular}{|l|} 
Sekis, \\
kuarsit, \\
gneis,
\end{tabular} & $\begin{array}{l}\text { Lithic } \\
\text { Eutrudepts }\end{array}$ & 237.336 & 27,6 \\
\hline 14 & $\begin{array}{l}\text { Pegunungan } \\
\text { tektonik }\end{array}$ & curam & $>1300$ & $\begin{array}{l}\text { Batupasir, } \\
\text { serpih, } \\
\text { lempung, }\end{array}$ & $\begin{array}{l}\text { Typic } \\
\text { Eutrudepts }\end{array}$ & 127.649 & 14,8 \\
\hline 15 & $\begin{array}{l}\text { Pegunungan } \\
\text { tektonik }\end{array}$ & curam & $>1300$ & $\begin{array}{l}\text { Sekis, } \\
\text { kuarsit, } \\
\text { gneis, }\end{array}$ & $\begin{array}{l}\text { Lithic } \\
\text { Haplustepts }\end{array}$ & 94.636 & 11,0 \\
\hline \multicolumn{6}{|c|}{ GRUP ANEKA (999) : } & 2.405 & 0,3 \\
\hline \multicolumn{6}{|l|}{ Total } & 860.789 & 100,0 \\
\hline
\end{tabular}




\subsection{Kesesuaian Lahan}

Evaluasi kesesuaian lahan dilakukan berdasarkan pencocokan antara karakteristik lahan dan persyaratan tumbuh/penggunaan lahan. Proses evaluasi kesesuaian lahan dilakukan menggunakan program ALES (Automated Land Evaluation System) yang diolah secara otomatis di program komputer. Penilaian dilakukan terhadap semua lahan, belum memisahkan antara lahan yang termasuk kawasan areal penggunaan lain (APL) dan kawasan kehutanan. Tanaman yang dinilai terdiri dari 4 komoditas unggulan perkebunan, yaitu: kelapa (Cocos nucifera), kakao (Theobroma cacao), pala (Myristica fragrans) dan cengkeh (Syzygium aromaticum).

Hasil penilaian kesesuaian lahan terhadap ke-4 komoditas tersebut disajikan pada Tabel 2, sedangkan penyebarannya tercantum dalam peta kesesuaian lahan namun tidak disajikan dalam tulisan ini karena keterbatasan ruang.

Dalam Tabel 3 terlihat, bahwa sebagian besar lahan di Pulau Buru, hampir mencapai $80 \%$ wilayah masuk dalam katagori tidak Sesuai (N), sedangkan sisanya masuk dalam katagori sesuai terdiri dari Sangat Sesuai (S1), Cukup Sesuai (S2), dan Sesuaia Marjinal (S3) untuk keempat komoditas unggulan yang dievaluasi. Td merupakan wilayah fisiografi grup aneka yang tidak dievaluasi dalam studi ini. Faktor pembatas lahan utama adalah lereng yang curam sampai sangat curam, elevasi diatas 700 $\mathrm{m}$ dpl, tanah dangkal, dan ketersediaan air (curah hujan rendah) pada daerah tertentu.

Perbaikan terhadap faktor-faktor pembatas biofisik cukup sulit untuk keempat komoditas unggulan perkebunan tersebut, sehingga potensi kesesuaian lahannya hampir tidak dapat ditingkatkan walaupun dilakukan perbaikan (improved). Hal ini berkaitan dengan lereng yang curam, tanah dangkal dan elevasi atau ketinggian diatas permukaan laut, dimana faktor-faktor tersebut masuk dalam faktor pembatas permanen yang tidak dapat diperbaiki.

\subsection{Pewilayahan Komoditas Unggulan}

Untuk menyusun peta pewilayahan komoditas unggulan, maka ditempuh beberapa tahapan sebagai berikut:

- Tahap pertama menentukan kombinasi tanaman unggulan berdasarkan potensi atau kelas kesesuaian, di mana (1) wilayah berpotensi sedang-tinggi apabila wilayah tersebut kesesuaiannya masuk katagori cukup sesuai dan sangat sesuai (S1-S2), (2) wilayah berpotensi rendah

Tabel 2. Hasil Evaluasi Kesesuaian Lahan untuk Komoditas Unggulan Perkebunan, P. Buru

\begin{tabular}{|l|r|r|r|r|r|r|r|r|}
\hline \multirow{2}{*}{$\begin{array}{l}\text { Kesesuaian } \\
\text { Lahan }\end{array}$} & \multicolumn{2}{|c|}{ Kelapa } & \multicolumn{2}{c|}{ Kakao } & \multicolumn{2}{c|}{ Pala } & \multicolumn{2}{c|}{ Cengkeh } \\
\cline { 2 - 9 } & $\mathrm{Ha}$ & \multicolumn{1}{c|}{$\%$} & \multicolumn{1}{c|}{$\mathrm{Ha}$} & \multicolumn{1}{c|}{$\%$} & \multicolumn{1}{c|}{$\mathrm{Ha}$} & \multicolumn{1}{c|}{$\%$} & \multicolumn{1}{c|}{ Ha } & \multicolumn{1}{c|}{$\%$} \\
\hline $\begin{array}{l}\text { Sangat } \\
\text { Sesuai (S1) }\end{array}$ & & & 44.632 & 5,2 & 51.597 & 6,0 & 51.597 & 6,0 \\
\hline $\begin{array}{l}\text { Cukup } \\
\text { Sesuai (S2) }\end{array}$ & 116.074 & 13,5 & 61.070 & 7,1 & 54.234 & 6,3 & 54.234 & 6,3 \\
\hline $\begin{array}{l}\text { Sesuai } \\
\text { Marjinal } \\
\text { (S3) }\end{array}$ & 81.452 & 9,5 & 73.039 & 8,5 & 64.147 & 7,5 & 64.147 & 7,5 \\
\hline $\begin{array}{l}\text { Tidak } \\
\text { Sesuai (N) }\end{array}$ & 663.265 & 77,1 & 682.047 & 79,2 & 690.810 & 80,3 & 690.810 & 80,3 \\
\hline Td & 2.405 & 0,3 & 2.405 & 0,3 & 2.405 & 0,3 & 2.405 & 0,3 \\
\hline TOTAL & 860.787 & 100,0 & 860.787 & 100,0 & 860.787 & 100,0 & 860.787 & 100,0 \\
\hline
\end{tabular}


apabila wilayah tersebut kesesuaiannya masuk katagori sesuai marjinal (S3), (3) wilayah tidak berpotensi apabila walayah tersebut kesesuaiannya masuk dalam katagori tidak sesuai.

- Tahap kedua melakukan overlay antara kombinasi tanaman yang potensial dengan penggunaan lahannya. Jika suatu lahan atau wilayah telah digunakan baik untuk pertanian maupun non pertanian dan bersifat permanen, maka pewilayahannya tetap seperti kondisi eksisting selama potensinya sesuai. Jika masih berupa alang-alang, semak-belukar dan hutan, maka pewilayahannya sesuai kombinasi komoditas yang potensial.

- Tahap ketiga adalah mengoverlay hasil tahap kedua dengan peta kawasan hutan. Hasil dari overlay ini adalah: (1) wilayah komoditas yang lahannya potensial di areal penggunaan lain (APL), (2) wilayah komoditas potensial di dalam areal kawasan hutan produksi yang dapat dikonversi, dan (3) wilayah yang potensial tetapi berada di kawasan hutan selain hutan produksi konversi tidak diwilayahkan untuk komoditas unggulan, walaupun lahannya potensial.

Berdasarkan hasil pewilayahan potensi dengan mempertimbangkan penggunaan lahan saat ini, maka pewilayahan potensi lahan untuk pengembangan komoditas unggulan perkebunan di Pulau Buru seperti disajikan dalam Peta 4, dan Tabel 3.
Tabel 3 menujukkan, bahwa lahan yang potensial untuk komoditas unggulan perkebunan (kelapa, kakao, pala dan cengkeh) hanya 187.902 ha atau $21,8 \%$ dari total luas Pulau Buru. Lahan yang potensial tersebut sebagian besar terdapat dalam kawasan hutan produksi konversi (HPK), yakni seluas 90.150 ha, dan dalam areal penggunaan lain (APL) adalah 13.173 ha. Lahan potensial yang menempati kawasan hutan lindung dan hutan lain yang tidak dapat dikonversi seluas 84.579 ha. Lahan potensial tetapi menempati kawasan hutan yang tidak dapat dikonversi memerlukan perijinan yang sangat sulit untuk dikembangkan sebagai kawasan perkebunan. Sedangkan lahan sisanya yang sangat luas sebagian besar tidak sesuai dan berada dalam kawasan hutan yang tidak dapat dikonversi (hutan lindung, hutan produksi, hutan produksi terbatas, dan cagar alam).

\section{KESIMPULAN}

- Hasil analisis penggunaan lahan/tutupan lahan dengan data satelit menunjukkan, bahwa sebagian besar lahan di Pulau Buru ditutupi hutan, namun sudah banyak hujan yang rusak dan ditumbuhi oleh semak belukar

- Satuan lahan pada fisiografi tektonik mendominasi wilayah ini. Satuan lahan ini mempunyai jenis tanah dominan inseptisol,

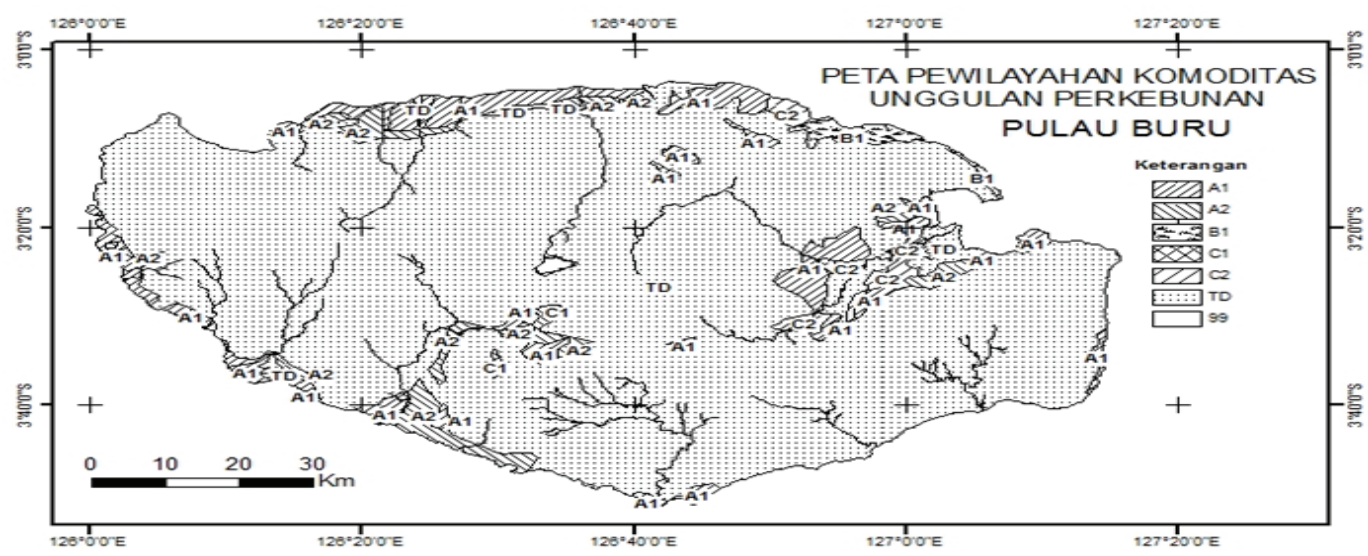

Gambar 4. Peta Pewilayahan Potensi Komoditas Unggulan Perkebunan 
Tabel 3. Pewilayahan Komoditas Unggulan Perkebunan Berdasarkan Status Lahan P. Buru

\begin{tabular}{|l|l|l|l|l|l|l|}
\hline Simbul & Pewilayahan-Potensi & \multicolumn{2}{l|}{ Status Kawasan } & \multicolumn{2}{l|}{ Luas } \\
\hline & & APL & HPK & HL, dll & Ha & $\%$ \\
\hline A1 & $\begin{array}{l}\text { Kelapa, kakao, pala, cengkeh-potensi } \\
\text { sedang-tinggi }\end{array}$ & 4.628 & 54.022 & 46.177 & 104.828 & 12,2 \\
\hline A2 & $\begin{array}{l}\text { Kelapa, kakao, pala, cengkeh-potensi } \\
\text { rendah }\end{array}$ & 1.147 & 26.342 & 36.626 & 64.116 & 7,4 \\
\hline B1 & Kelapa, kakao, potensi sedang-tinggi & 2.568 & 4.087 & - & 6.654 & 0,8 \\
\hline C1 & Kelapa-potensi sedang-tinggi & & 1.185 & 101 & 1.286 & 0,1 \\
\hline C2 & Kelapa-potensi rendah & 4.830 & 4.514 & 1.675 & 11.019 & 1,3 \\
\hline TD & Tidak berpotensi & 12.013 & 150.417 & 510.455 & 672.885 & 78,2 \\
\hline T O T A L & 25.185 & 240.568 & 595.034 & 860.787 & 100,0 \\
\hline
\end{tabular}

Keterangan: APL= Area Penggunaan Lain; HPK= Hutan Produksi Konversi; HL dan Lainnya $(\mathrm{HP}=$ Hutan Produksi; HL= Hutan Lindung; CA MASBAIT= Cagar Alam)

relief berombak sampai curam dengan bahan induk tanah adalah Napal, batupasir, batuan serpih.

- Sebagian besar Pulau Buru, yaitu hampir mencapai $80 \%$ wilayah masuk katagori Tidak Sesuai $(\mathrm{N})$ untuk keempat komoditas unggulan, sisanya masuk katagori sesuai, baik Sangat Sesuai (S1), Cukup Sesuai, maupun Sesuai Marjinal. Faktor pembatas utama lahan adalah lereng yang curam sampai sangat curam, elevasi diatas $700 \mathrm{~m}$ dpl, tanah dangkal, dan ketersediaan air (curah hujan rendah) pada daerah tertentu, sehingga sulit untuk diadakan perbaikan

- Lahan potensial untuk pengembangan komoditas unggulan perkebunan seluas 187.902 ha, dan sebagaian besar masuk dalam kawasan hutan produksi konvesi (HPK), yaitu 90.150 ha, sehingga untuk pengembangannya perlu adanya perijinan konversi lahan.

\section{DAFTAR PUSTAKA}

1. Badan Pusat Statistik (BPS), 2010. Hasil Sensus Penduduk tahun 2010. SP2010.

2. FAO. 1976. A Framework for Land Evaluation. Soil Resources Management and Conservation Service Land and Water Development Division.
FAO Soil Bulletin No. 32. FAO-UNO, Rome.

3. CSR/FAOStaffs. 1983. Reconnaissance Land resource Sirvey $1: 250.000$ Scale.

Atlas Format Procedures. AGOF/ INS/78/006. Manual 4. Version 1. Centre for Soil Research, Bogor. Indonesia.

4. Djaenudin, D., Marwan H., Subagyo H., dan A. Hidayat. 2003. Petunjuk Teknis untuk Komoditas Pertanian. Edisi Pertama tahun 2003, ISBN 9799474-25-6. Balai Penelitian Tanah, Pusat Penelitian dan Pengembangan Tanah dan Agroklimat, Badan Litbang Pertanian.

5. Hardjowigeno S., dan Widiatmaka, 2001. Kesesuaian Lahan dan Perencanaan Tataguna Tanah. Jurusan Tanah, Fakultas Pertanian, Institut Pertanian Bogor.

6. Tjokrosapoetro, S., T. Budhitisna, and Erusmana. 1993. Peta Geologi Lembar Pulau Buru. Pusat Penelitian dan Pengembangan Geologi Bandung.

7. Van Bemmelen, RW. 1970. The Geology of Indonesia Vol 1A. MartinusNijhoff. The Hague.

8. Soil Survey Staff, 2003. Keys to Soil Taxonomy. Ninth Edition. United States Departement of Agriculture. Natural Resources Conservation Services. 